\title{
Rivers in Deluge: Degradation and Ecological Restoration in the Poems of A. K. Ramanujan and Keki N. Daruwalla
}

\author{
Hema S, Hitha Haridas, Nimisha P
}

M.A. English, PG from a College Affiliated to University of Calicut, Kerala, India

Received: 26 Mar 2021; Received in revised form: 03 May 2021; Accepted: 20 May 2021; Available online: 13 Jun 2021

(C)2021 The Author(s). Published by Infogain Publication. This is an open access article under the CC BY license

(https://creativecommons.org/licenses/by/4.0/).

\begin{abstract}
Our entire human civilization is said to have originated on the banks of rivers. It continues to provide us with food, water and livelihood. The same rivers today are black and muddy. We live in a world where culture has superimposed nature causing errands of natural disasters. Natural disasters occur as a result of human greed and exploitation. A River by A. K. Ramanujan and The Ghaghra in Spate by Keki N. Daruwalla are often compared poems about rivers in deluge. The paper aims to look at these poems from an ecological perspective.
\end{abstract}

Keywords - Conservation, destruction, ecocriticism, ecosystem, environment, green studies, Indian poetry, river.

\section{INTRODUCTION}

Indian ecology has been a subject matter in the texts produced from the subcontinent. Be it poets or dramatists, to depict what truly holds Indians is to paint its majestic mountains and mellifluous rivers. Just like the romantics of the Britain and America, Indian poets celebrate nature to its epoch. From Rabindranth Tagore to Sarojini Naidu and modern poets such as Keki Daruwalla and A.K Ramanunjan, the ensemble literature explores India in its width and girth. Nature appears in myriad shapes and forms.

River is an integral part of our ecosystem. Entire of human civilization flourished on its banks. Yet when the rivers turn malevolent, they cause flood and destruction. Afraid of this wrath we to this day pray and give tributes to the river Gods.

\section{ECOCRITICISM}

Ecocriticism is broadly termed as the study of the relationship between literature and the physical environment. The word 'ecocriticism' traces back to William Rueckert's essay, published in 1978 Literature and Ecology: An Experiment in Ecocriticism. The term was further used by Karl Kroeber in the essay Home at
Grasmere, wherein he used the term 'ecological' in literary criticism. Rachel Carson's Silent Spring (1962) urged for immediate attention to nature and its depleting resources was a wakeup call to the literary genre. Cheryll Glotfelty popularly acknowledged as the founder of U.S Ecocriticism, "urged its adoption to refer to the diffuse critical field that had previously been known as the study of nature writing" (Barry 249).

Glotfelty, in her collections of essays titled Ecocriticism Reader (1996), defines ecocriticism as an "earth centred approach to literary studies" (Glotfelty 18). Ecocriticism in the US takes its literary bearings from the nineteenth century transcendentalists. While in the UK, Ecocriticism/ Green Studies was influenced by the British Romanticism and emerged through major critics such as Jonathan Bate, Raymond Williams and Lawrence Buell.

Lawrence Buell's The Future of Environmental Criticism talks of waves in ecocriticism- the first wave, preoccupied with nature writing, romanticizing the wilderness, whereas the second wave critiqued and spoke of environmental concerns. Greg Garrard, in the introduction to The Oxford Handbook of Ecocriticism says, "Bull's wave metaphor and Kate Soper's distinction between nature endorsing and nature sceptical perspectives are both useful to characterize the history and development 
of ecocriticism" (Garrard 11). She goes a step ahead to think them as centripetal and centrifugal forces "Centripetal posture is a huddle, the protectiveness of which is hard to dissociate from defensive, exclusionary parochialism" (12). National parks are an example for this wherein they provide protection and sustain endangered species. Centrifugal is "fascinated by the hybrid spaces, cosmopolitan identities and nature culture ironies" (12).

Joseph Meeker in his The Comedy of Survival (1974) proposed that environmental crisis is caused by a culture tradition in the west which separates culture form nature and gives culture more dominance. "For an ecocritic, nature really exists, out there beyond ourselves ... it is present as an entity which affects us, and which can affect, perhaps fatally, if we mistreat it" (Barry 252). Nature cannot be reduced to a concept "which we conceive as part of our cultural practice" (Barry 252). Ecocriticism constantly questions the theories which generally see the world as "socially and linguistically constructed" (Barry 252). The eco reading thus, looks out to the environment rather than into the psychology; emphasise on factual writing and "turn away from social constructivism and linguistic determinism” (Barry 270).

\section{ENVIRONMENTAL DILEMMA IN A RIVER BY A. K. RAMANUJAN}

Attipat Krishnaswami Ramanujan occupies a prominent place in the cosmos of Indo-Anglican Poetry. He earned the name and fame all over the world after the publication of his two volumes of poetry "The Striders" (1966) and "Relations" (1971). Ramanujan's poetry in English has the ability to assimilate and accommodate linguistics, literary and cultural features of Kannada and Tamil into English literature. King Bruce observes, "He showed that Indian poets could both be modern and work from within their own literary traditions" (22). The environmental awareness is also quite evident in the poetry of A K Ramanujan.

A K Ramanujan's A River is the finest poem taken from his magnum opus; The Striders (1966). The poet in the poem speaks of the river 'Vaikai' which flows through Madurai, the "city of temples and poets" (Parthasarthy 98). 'Vaikai' finds a special place in Tamil Literature as it is akin to the Tamil culture and its people.

A River is a poem which describes the destruction and the destructive face of 'Vaikai'. Ramanujan describes the peninsular nature of 'Vaikai' that, it dries up in summer and is flooded during monsoon, thus exposing both phases of the river. But he observes that the poets of all times- past and present only speak of the river in deluge. "Poets sang only of the floods", just like "the new poets who still quoted the old ones" (98). They are indifferent to the sufferings of both river and to human sorrow and their poetry lacks consideration for their fellow beings. Ramanujan criticises the poets who do not see the problems of drought as well as flood.

According to M K Naik, "In poetic technique, of all his contemporaries, Ramanujan appears to have the surest touch, for he never lapses into romantic cliché" (201). He finds that the river during summers goes unnoticed by the poets; the river in spate during floods induces the poets to be poetic. He notices that the poets of the past and the present only versify on the river during the floods. They merely imitate the older poets and do not try to look beyond this:
every summer
a river dries to a trickle
in the sand baring the sand-ribs,
straw and women's hair
clogging the watergates (98)

The condition of the river in every summer is pathetic; it is due to the construction of dams and other harmful depredatory attitude of man against nature. Madurai was initially a city of culture, where the poets drew their inspiration from its spiritual heritage has today started to disintegrate. The river dries to the sand and it appears to be an empty land where there is not even a single species during summer. The Watergate is full of rust and hair of the women with the straws stuck to it. As the sun's rays fall on the wet rocks they appear as the sleeping crocodiles and the dry ones look like the water buffaloes.

With the arrival of monsoon, the same 'Vaigai' starts to swell up inciting people's interest from the city. They actively take part in reporting the inching waters, the houses that have been washed away and the probability of rains still continuing. Ramanujan accuses as he says "The poets sang only of the floods" (98). It is not just the common folk but also the poets of the land who take a keen interest in the flood. Water gushing into houses, stranded cattle, floating people and utensils is not a happy site to look at. He ridicules the society when he very specifically names the cows Gopi and Brinda all the while addressing "pregnant woman drowned with perhaps twins in her" as a nameless, common folk (98). Ramanujan says that "the river has water enough to be poetic about only once a year" (99).

According to R. Parthasarathy, A K Ramanujan's poetry is "rooted in and stem from the Indian environment and reflects its mores, often ironically" (3). He spoke about the miseries caused by the river and the misery caused to the river. The reality of the river is exposed. Ramanujan avoids nostalgic subjectivity and brings the 
interpretation of the river that causes havoc and suffering to people during floods. Parthasarathy aptly says that the poem ironically contrasts "the relative attitude of the old and new Tamil poets, both of whom are exposed for their callousness to suffering, when it is so obvious, as a result of the flood" (95). The poet employs the heart wrenching images like pregnant women who are drowned in the floods. Ramanujan clarifies the legitimate function of the genuine poetry by reflecting the real social realism through his poems.

The poem throws light on the dark side of the river namely the destruction and the disaster it causes to the lives during floods. The repetition of the words like pregnant woman and the cows named Gopi and Brinda signify Ramanujan's concern for the plight of the living beings in the world, which he shares life along with them. His keen observation on nature is revealed through the poem.

According to K Sumana "The poet narrates the poem through the mouth of a visitor to make it objective. The greatness of the poem lies in the fact that the traditional praise for the river has been contrasted with what is actually experienced by the people in the floods" (Sumana 41). The poet's concern in the poem is utterly humane that binds other perspectives together; thereby presenting successfully a whole picture of the poetic essence of a river. Thus, Ramanujan brings the human concern that was missing even from the past and he manifests his environmental awareness and pays considerable heed to the conservation of natural objects.

\section{MULTIPLE DIMENSIONS OF RIVER IN THE GHAGHRA IN SPATE BY KEKI N. DARUWALLA}

Keki N. Daruwalla is considered to be one of the distinctive and innovative poetic voices of the Indian literary scene. Critic M. K. Naik points out that "Daruwalla is one of the major voices in the IndoAnglican tradition of poetry" and "one of the most substantial Indo-Anglican poets" (Mondal 39). Daruwalla's The Ghaghra in Spate highlights the transformation of an ordinary river into a violent and rebellious river that marks the arrival of flood which in turn results in the dangerous situation of people's helplessness and death.

The poem belongs to the collection titled Under Orion and it is based on the river Ghaghra. This poem has been recognized as a remarkable comparison to the poem A River written by A. K. Ramanujan. The title of the poem is significant in nature as Ghaghra is the name of a river, also known as 'Karnali' and the word 'spate' means "a sudden flood in a river." Hence, the title of the poem points to the situation of flood.

The poet suggests that river often becomes a woman since the flow of river is distracted similar to how a woman's sleep gets disturbed due to circumstances. In the evening, the river becomes dry which represents gloom and death. Daruwalla mentions, "In the afternoon she is a grey smudge/ exploring a grey canvas" (Daruwalla 4-5). Here, the poet mentions the state of river before the arrival of flood. This reveals the fact that river has the ability to become a destructive force as the ultimate aim of river is mainly to cause threat to the existence of ecological system. The negative approach of man towards nature is moreover reflected in nature's attitude towards man, in the form of flood.

Vrinda Nabar remarks, "The River's rhythm is that of life and death, of birth and rebirth, of passion and rejection" (Mondal 34). River, identified as the spinal cord of village enhances vegetation and provides adequate water to the villagers. Waste deposition contaminates water bodies, which leads to harmful effects, ending in plenitude of health problems and environmental disasters. Human beings are themselves responsible for the flood episode and they happen to be the victims and survivors of the particular incident. Violence overpowers silence and Daruwalla writes:

She flees from the scene of her own havoc

Arms akimbo, thrashing with pain

Behind her the land sinks

Houses sag on to their knees

In a farewell obeisance. (61-65)

The circular movement of the river terrifies villagers where the poet gives the picture of an "illtempered" and "cruel ghost" taking away anything that appears before her (Rajalakshmi 91). River symbolises vengeance because of its existence as a subverted element in human hands for centuries. Water has heavily entered the land followed by the submerging of buildings, houses and organisms in water. The condition becomes complicated since people are incapable of escaping from the havoc caused due to flood.

The movement of water is devoid of calmness and sympathy as it takes up the position of a predator with the ultimate aim of human exploitation. The enraged river has been affected by madness until it gradually recedes and recovers its normal state of existence.

Daruwalla, known as "nature poet, beautifully "romanticizes nature with a sense of ecstasy" (Mondal 33). Daruwalla depicts river as a "cunning animal" and attributes "animal presence" to river (Mondal 35). As far as the poem is concerned, Ghaghra is an "angry river" that 
attacks the village wherein all the constructed structures are entirely collapsed (Mondal 35).

Perhaps, human beings can easily comprehend the character of river and flood has been a routine affair that occurs every year because it has transformed into a yearly phenomenon. They gather absolute confidence and strength to face the consequences of flood and they are full-fledged to encounter the miserable condition.

Naik mentions that Daruwalla's achievement equals "Nissim Ezekiel's achievement in the field of poetry even though his themes and his style are entirely different" (Mondal 39). Daruwalla explores the plight of river, subjected to continuous degradation. The river transforms into "a storehouse of junk" and a space for the conduct of "unholy and unhealthy" endeavours (Mondal 39). River symbolises traditional value and essence of the diversity of India. Human life depends on water resources largely and hence, a nation without these natural elements itself is incomplete and worthless.

\section{CONCLUSION}

Ecocriticism or Green Studies developed as a critical approach in the late 1970s in the USA and early 1990s in the UK. The Association of the Study of Literature and Environment (ASLE) in 1992 was co founded by Cheryll Glotfelty. Early writings on nature bear impressions of romanticism. It is only in the later years, the idea developed as an "ism" or rather a branch of literary theory. Ecocritics inspect the representation of nature in literature. A range of concepts under the term Ecocriticism has developed since then.

Ecology for a long time now has been vehemently exploited. With the depleting natural resources and adding pollution, we are moving forward to an age that will be engulfed in smog and foam.

Anglo Indian poets of all times have romanticised the lush beauty of India, its vast diversity and landscape. The generation of modern poets such as A.K Ramanujan and Keki N. Daruwalla advocates the need for conservation and protection of our environment. Their poems such as A River and Ghaghra in Spate speak of river Vaikai and Ghaghra respectively; depict rivers and their multiple personalities. We often look at rains as a symbol of hope and happiness but what happens when the rivers over flow leaving thousands of people and cattle stranded. River banks are exploited to satisfy commercial needs, the rampant deforestation and constructing buildings has resulted in an abnormal increase of natural disasters. Flood in the poems become a perfect example for this. The Rivers prompt humans to think and act in such a manner as to show respect, affection and concern for nature as well as fellow human beings. The hypocrisy of poets and the aftermath of floods are exposed. Rivers cannot be romanticised always. It can be cruel and deadly.

Environmental conservation and sustainable development must be a lot more important and essential for the survival of human race lest, we would only leave behind a waste land.

\section{REFERENCES}

[1] Barry, Peter. (2018). Beginning Theory: An Introduction to Literary and Cultural Theory.Viva Books.

[2] Daruwalla, Keki N. The Ghaghara in Spate- A Poem by Keki N Daruwalla. Retrieved from www.poemhunter.com/poem/the-ghaghra-in-spate-a-poemby-keki-n-daruwalla/

[3] Garrard, Greg. (2014). The Oxford Handbook of Ecocriticism, Oxford University Press.

[4] Glotfelty, Cheryll and Harold Fromm, editor. (1996). The Ecocriticism Reader: Landmarks in Literary Ecology.

[5] King, Bruce. (1987). Modern Indian Poetry in English. Oxford University Press.

[6] Mondal, Bidhan. (2014, December). Painting Riverscapes with the colour of Poetry: the Unvarnished Reality in K. N. Daruwalla's River Poems. Bhatter College Journal of Multidisciplinary Studies, vol. 4, pp. 32-40. bcjms.bhattercollege.ac.in/V4/05_K_N_Daruwalla_River_ Poems.pdf

[7] Naik, M. K. (1982). A History of Indian English Literature. Sahitya Akademi.

[8] Parthasarthy, R. (1976). Ten Twentieth-Century Indian Poets. Oxford University Press.

[9] Rajalakshmi, M. (2018, April). Keki N. Daruwalla's Craftsmanship. Literary Herald, vol. 3, issue.6, pp. 88-95. tlhjournal.com/uploads/products/13.m.rajalakshmiarticle.pdf

[10] Sumana, K. (1996). A Realistic Look at Ramanujan's A River, Indian Writing Today, edited by C. R. Visweswara Rao, IAES, p. 41. 